Cornell Law Library

Scholarship@Cornell Law: A Digital Repository

Cornell Law Faculty Publications

Faculty Scholarship

2001

\title{
Public Funding for Religious Schools: Difficulties and Dangers in a Pluralistic Society
}

Laura S. Underkuffler

Cornell LawSchool, lu27@cornell.edu

Follow this and additional works at: http://scholarship.law.cornell.edu/facpub

Part of the Constitutional Law Commons, First Amendment Commons, and the Religion Law Commons

\section{Recommended Citation}

Underkuffler, Laura S., "Public Funding for Religious Schools: Difficulties and Dangers in a Pluralistic Society" (2001). Cornell Law Faculty Publications. Paper 909.

http://scholarship.law.cornell.edu/facpub/909

This Article is brought to you for free and open access by the Faculty Scholarship at Scholarship@Cornell Law: A Digital Repository. It has been accepted for inclusion in Cornell Law Faculty Publications by an authorized administrator of Scholarship@Cornell Law: A Digital Repository. For more information, please contact jmp8@cornell.edu. 


\section{Public Funding for Religious Schools: difficulties and dangers in a pluralistic society}

\section{LAURA S. UNDERKUFFLER}

ABSTRACT In the United States, payment of public tax money to religious institutionsincluding religious educational institutions-has traditionally been subject to rigorous restraints. Interpreting the First Amendment to the United States Constitution, the Supreme Court has long held that state-mandated financial support of religious institutions tends to corrupt both religion and government, and is a violation of conscience for those who must fund religions with which they may bitterly disagree. Recently, advocates of state aid for religious education have attacked these principles, arguing that they fail to recognise the religious tolerance that American society has achieved. This article defends the traditional restraints. It argues that Americans in fact embrace a limited form of religious diversity, one that tends to be tolerant of familiar, mainstream religious groups, but is distinctly intolerant of others. Indeed, recent polls indicate that the equal funding of all religious groups - as the Constitution's principle of equality would demand-is highly controversial and supported by few Americans. It is argued that traditional restraints on public funding of religious institutions in the USA are rooted in a fundamental truth: that religious differences in pluralistic societies are often deep, divisive, and volatile, and that the financial enmeshment of religion and government serves neither religion, government, nor the atmosphere of tolerance upon which diverse societies depend.

\section{INTRODUCTION}

The idea of state funding for religious elementary and secondary schools implicates some of the deepest tensions that run through the general field of church-state relations. In any setting in which public money is paid to religious institutions, concerns about the enmeshment of religion and government are presented. When-in additionthe institutions to be funded are elementary and secondary schools, the problems are multiplied. In addition to the usual concerns, there are conflicting convictions about the rights of parents to direct the schooling of their children, and the belief that schools are civic institutions which must work toward the inculcation of civic values and civic ideals. The passions that accompany such issues are intensified when religious pluralism threatens the confidence of parents and other citizens that the values that the state wishes to inculcate, or that religious schools will teach, are compatible with their own.

As a society with historical and increasing pluralism, the United States has long grappled with these issues. The political and legal cultures in the United States have long proclaimed the sanctity of religious freedom, the importance of parental rights, and the role that educational institutions play in the inculcation of civic values. Yet how all of these goals can be simultaneously realised has been anything but clear. 
In recent years, the First Amendment to the United States Constitution has provided the most important battleground for struggles among competing visions of religious freedom, parental rights, and educational guarantees. This Amendment, which guarantees the free exercise of religion and prohibits the establishment of religion by government, determines the final, national standard to which all governments-federal, state and local-must adhere. Since 1940, the United States Supreme Court has issued more than thirty important decisions dealing with the religious freedom guarantees of the First Amendment in educational settings. These cases have involved issues as diverse as publicly provided books for religious-school students, the conducting of prayer in public schools, the application of compulsory education laws to religious objectors, and objections to the teaching of religiously based or secularly based curricula in public elementary and secondary schools.

The restrictions that the Supreme Court has imposed when resolving these conflicts have not always been received with universal acceptance or acclaim. Members of religious communities, in particular, have resisted ideas that 'God has no place' in public schools or that private religious educational institutions should not be funded on a par with secular ones. In the past, resistance was largely confined to the advancement of plans which were (advocates hoped) factually distinguishable from previously invalidated ones. Very recently, however, advocates for state funding of religious schools have launched a far more fundamental challenge to the Court's previously imposed restrictions, attacking - in particular - the idea that religious beliefs and religious institutions involve special dangers and require special protections that justify the exclusion of religious schools from state funding schemes.

In order to understand the posture of these issues in the United States, it is necessary to have some awareness of the historical record upon which First Amendment law has been constructed. From the time of the Supreme Court's first important First Amendment case dealing with an alleged establishment of religion by government [1], the history which surrounded the adoption of the First Amendment has been an important judicial starting point for understanding the Constitution's vision of church-state relations. Indeed, of all areas of constitutional inquiry, questions of church-state relations have been most closely tied-traditionally, at least- to historical understandings.

Although Americans often believe that the American colonies were characterised by an atmosphere of religious freedom, the reality was in fact quite different [2]. Although many individuals came to North America in pursuit of religious freedom for themselves, rarely did they extend that ideal to others. In the 17 th and 18 th centuries, religious oppression and persecution characterised virtually all of the American colonies. Quakers, Baptists, Roman Catholics, Jews, and Unitarians were particular targets for persecution. Criminal penalties, civil disabilities, and other sanctions were imposed if individuals persisted in the exercise of forbidden faiths, refused to affirm the tenets of the dominant faith, or otherwise offended majority religious sensibilities. Citizens were also taxed for the support of established Christian churches, a practice which engendered particularly bitter opposition.

By the time of the American Revolution, religious dissenters could be found throughout the colonies. In the colony of Virginia, for instance, nearly two-thirds of its citizens were dissenters by the time that independence was declared. As the numbers of religious dissenters grew, struggle against all forms of religious establishment intensified. Dissenters were vocal and stridently partisan, and merged their cries for religious freedom with the cries for political freedom that were sweeping the colonies. 
Despite widespread agitation against the existing religious regimes, the Constitution as originally drafted and submitted to the states for ratification contained only one religious freedom guarantee: that no religious test-oath would be required for any federal office [3]. The omission of a more extensive guarantee is generally attributed to the framers' view that the national government simply had no role whatsoever to play in church-state relations - that issue remaining, in this view, the province of state governments. However, many delegates to state ratifying conventions did not wish to leave such an important issue to simple negative implication; they demanded, as a condition for ratification, that protection against religious oppression by the newly formed federal government be more explicitly guaranteed. As a result, the First Amendment to the Constitution was drafted and ratified. This Amendment states that 'Congress shall make no law respecting an establishment of religion, or prohibiting the free exercise thereof ...' [4]. For many years, it was assumed that this Amendment restrained the federal government, and the federal government only. It was not until the 1940s that the Free Exercise and Establishment Clauses of the First Amendment were held by the United States Supreme Court to constrain state governments as well [5].

As a result of this history, and subsequent Supreme Court interpretations of it, several principles involving the meaning of religious freedom have become entrenched as a matter of First Amendment law and public understanding. First, religious toleration and freedom of conscience are viewed as essential characteristics of a free society, to be recognised - and enforced - by all levels of government. Second, all persons-religious and nonreligious - must be treated equally by law. Third, government must not - through its policies or practices - establish a particular religion to the exclusion of others. There must be institutional separation of church and state.

Stating these principles is one thing; implementing them is another. How these principles should be implemented in particular settings has engendered great difficulty and controversy. This is particularly true where the settings involved are elementary and secondary schools.

\section{THE RELIGION CLAUSES OF THE FIRST AMENDMENT: EXISTING PRINCIPLES}

The religion clauses of the First Amendment-one which guarantees free religious exercise, and the other which prohibits the establishment of religion by governmentseem, at first glance, to be analytically separate guarantees. The Free Exercise Clause seems, by its terms, to protect individual activities from government: space is created, by this guarantee, for free religious exercise and free religious belief. The Establishment Clause, on the other hand, seems, by its terms, to concern the activities of government itself: government is precluded, by this guarantee, from the establishment of particular religious doctrines or particular religious creeds.

The separability of these guarantees quickly becomes difficult, however, on both theoretical and practical levels. In some situations, the guarantees can be seen as reinforcing the same values: for instance, we prohibit the establishment of religion by government in order to protect its free exercise by other (dissenting) individuals. In other situations, the guarantees are clearly at odds. For instance, the protection for religious exercise - and only religious exercise-seems, on some level at least, to be an establishment of religion (in a generic sense) by government. Because such intertwined considerations are particularly acute in school funding cases, I will first briefly sketch existing doctrinal outlines of both Free Exercise and Establishment Clause guarantees. 


\section{Free Exercise of Religion}

The importance of free religious exercise, and its protection from infringement by government, are bedrock themes in First Amendment jurisprudence. The Supreme Court has repeatedly stressed the strength of this constitutional guarantee, stating, for instance, that '[f]reedom of thought, which includes freedom of religious belief, is basic in a society of free men.' [6]

Religious exercise may be comprised of belief or action; and although belief may be protected absolutely, action obviously cannot [7]. Important state interests will often conflict with actions that are claimed to be compelled by religious imperative, and sometimes the maintenance of civil society will require that state interests prevail. Under the Court's traditional test-consistently applied until the last decade-a particular act was protected as religious exercise if it was required by a central religious belief, was substantially burdened by a government action, and was not outweighed by a compelling state interest [8]. Under this test, substantial protection was afforded to claimed religious exercise when pitted against state laws. For instance, in a ruling which was (perhaps) the high water mark for this test, the Court held that Amish religious beliefs which required the discontinuance of a child's education after the eighth grade of elementary school must be given precedence over the state's competing interest in universal childhood education [9].

The compatibility of the compelling interest test with the realities of governing a complex, pluralistic society was, however, always a serious issue; and in two cases decided a decade ago, the Supreme Court abruptly shifted course. In these cases, the Court held that only when an individual is coerced by government to act in violation of his or her religious beliefs must a compelling government interest be shown. In all other cases, government need only show that the law has no 'anti-religious bias', i.e., that religious and non-religious individuals and actions are treated equally in intention and effect. If a law is 'neutral' in this sense, the fact that it incidentally burdens religious conduct presents no First Amendment question [10]. '[W]e cannot', the Court wrote, 'afford the luxury of deeming presumptively invalid, as applied to the religious objector, every regulation of conduct that does not protect an interest of the highest order.' [11]

The abandonment of the compelling interest test for one rooted in the simple demand for neutrality in law exposes one of the central issues in First Amendment jurisprudence: the extent to which equal treatment is, in the end, the most important-or the only-substantive First Amendment guarantee. This is a question which has become particularly prominent in Establishment Clause controversies, an area to which we now turn.

\section{Freedom from Establishment of Religion by Government}

The principle of 'freedom from establishment of religion by government' means-in some form - the separation of religion and government. Although religiosity is certainly a permissible characteristic for individuals who serve in governmental capacities-for instance, the Court has held that a leader of a religious order cannot, on that ground, be excluded from government service [12] - the Establishment Clause attempts to maintain some separation of religion and government as a way to accommodate the natural strains of religious pluralism and to foster tolerance of divergent religious views.

Over the years, the Court has identified three forms of establishment of religion by government that are particularly problematic from a constitutional point of view. These 
are: state favouritism toward particular religious (or nonreligious) groups; the granting of state financial support to religious institutions; and the assumption by religious institutions of essentially public functions.

Eliminating the first form of establishment - that of government favouritism towards particular religious (or nonreligious) groups - has been a part of the struggle for religious liberty since the American colonial period. Colonial laws and practices that favoured members of some religious sects over members of others were bitterly resented, and the end of such schemes was one of the primary goals of reformers. In more recent times, the principle of equality among religious groups, and among those who are religious and those who are not, has been strongly and consistently affirmed by the Court through five decades of Establishment Clause jurisprudence. The Court has repeatedly stated that the state must favour 'neither one religion over others nor religious adherents collectively over nonadherents.' [13] The reasons are simple. 'When the power, prestige, and financial support of government [are] placed behind a particular religious belief, [there is] ... indirect coercive pressure upon religious minorities to conform ...,' [14] violating the principle of freedom of conscience. In addition, state favouritism toward some makes political outsiders of others-leading to political division and strife, 'principal evils against which the First Amendment was intended to protect.' [15]

This idea of equality is not, of course, without its difficulties. Although it is fairly easy to prohibit the explicit establishment of a particular religious sect by government, 'religion in government' is arguably more than announced institutional affiliations. It may no longer be acceptable for government to pronounce this a 'Christian nation', or to condition benefits upon the existence (or non-existence) of an applicant's beliefs; but vague judicial references to 'Judeo-Christian principles' in lawmaking are tolerated, and the particular values that government routinely implements are certainly more in keeping with majority religious views than they are with minority ones. Indeed-one could argue - the idea that nonreligion cannot be preferred to religion in government policies and practices is impossible to implement, since government-sponsored activities must have some kind of content, which will—inevitably — be aligned with some point of view. If, for instance, a public school curriculum reflects religious teachings, it violates the guarantee of equal treatment of all religious groups; if it reflects secular teachings, it violates the religion/nonreligion equal-treatment guarantee [16].

As the result of such problems, the federal courts have generally rejected the notion that the mere congruence of the values implemented by government with particular religions or nonreligious tenets is enough to violate the Establishment Clause. There must, in addition, be the identity of government with a particular religion or religions, or the identity of government with hostility to religion or nonreligion, to trigger constitutional guarantees. Thus, in public school settings, for instance, the leading by teachers of Bible reading or other religious exercises [17], or the choice of a curriculum with the attention and effect of advancing particular religious objectives [18], has been held to violate the Establishment Clause.

The second form of establishment - that of state financial aid for religious activities or religious institutions - has proven to be an area of particularly intractable doctrinal difficulty. In one of the few clear rules in this area, the giving of unrestricted cash grants to religious institutions has been held by the Court to be a violation of the Establishment Clause. In Everson v. Board of Education, decided in 1947, the Court declared that no state can, 'consistently with the 'establishment of religion' clause of the First Amendment [,] contribute tax-raised funds to the support of an institution which 
teaches the tenets and faith of any church.' [19] In later years, the Court clarified that state aid may be given to religious institutions if restricted for use in the performance of secular services or the conducting of secular activities [20]. Where, however, such services or activities are 'subsumed in the religious mission',[21] or are intended to 'assure future adherents to [the sponsoring religious organization's] ... particular faith', [22] direct monetary grants of state funds for their support has been prohibited. Because the Court has believed that religious and secular teachings in religious elementary and secondary schools are-as a practical and legal matter-inextricably intertwined, the giving of unrestricted cash grants of state funds to such institutions has long been prohibited [23].

The prohibition upon the direct payment of state funds to religious institutions, when those funds will be used for religious purposes, is rooted in several serious concerns. First, the Court has believed that state-mandated financial support of the religions of others is a violation of conscience for those who must pay. Although taxpayers are routinely required to fund policy choices that the majority determines, and with which those taxpayers might well disagree, compelled financial support of the religions of others is believed to be a far more intrusive and coercive matter. In addition, the Court has adhered to the belief that the financial enmeshment of church and state 'tends to destroy government and to degrade religion.' [24]. Religious institutions are corrupted as they scramble for government largesse, and government is undermined as religious issues become political issues, and political differences become increasingly scored along religious lines [25].

The extent to which these concerns require the prohibition of 'indirect' aid to religious institutions has proven to be a much more doctrinally difficult question. The Court has long recognised that it would be impossible - indeed, undesirable - to exclude religious institutions from public goods and services (such as police and fire protection) that are provided, of necessity, to others. The provision of basic services necessary for religious institutions to coexist with others as good neighbors seems to be simply an exercise in common sense. Where to draw the line beyond the provision of such basic services is, however, a difficult question.

'Indirect' public financial aid to religious institutions-such as the provision of textbooks, transportation services, or testing services to religious school students-has traditionally been upheld if the aid is (itself) secular in nature and provides only 'incidental financial benefit' to the recipient religious institution [26]. The theory seems to be that if such institutions serve secular as well as religious functions, secular aid can be used (and confined) to the secular functions which such institutions perform [27]. The requirement that such aid confer only incidental financial benefit is intended to minimise the financial enmeshment of religion and government, with its dangers of political and social divisiveness and the corruption of both religious and government institutions.

Whether these tests for indirect aid are workable is open to serious question. If, for instance, the recipient institution is a religiously affiliated elementary school, in which teaching activities are 'subsumed in the religious mission', the idea that religious and secular functions can be separated - with state aid used only for the latter-is likely a completely unrealistic one. In addition, prohibited cash ('direct') aid and permitted non-cash ('indirect') aid are the same in a very significant way: they pay for expenses that religious schools would otherwise incur, freeing the resources of those schools for use in other (religious) activities. The assurances that such aid does not 'supplant' 
services offered in the religious school [28], or that it creates no 'financial incentive [for individuals] to undertake religious indoctrination' [29], does not eliminate this reality.

In a very recent case, a plurality of the Court employed a very different model for approaching state-aid cases. Mitchell v. Helms [30], decided in 2000, involved a challenge to a federal programme under which computers and other technical materials and services were purchased with federal money by local school districts, and distributed as 'loans' to all schools within the districts' geographic boundaries, including religious schools. Six justices voted to uphold the constitutionality of the programme. Two did so along traditional lines-on the grounds that the aid was itself secular in nature, and provided only incidental financial benefit to religious schools. Four advanced a new approach. They argued that Establishment Clause concerns can be reduced to a single principle: whether the government action can reasonably be said to involve government 'indoctrination' in religion generally or in a particular religious faith. If the aid is 'neutral' - if it is 'offered to a broad range of groups or persons without regard to ... religion'-then it is unreasonable to conclude that any indoctrination has been done at government behest [31].

The idea that government aid - no matter how massive-can be given to religious institutions, as long as it is done on a 'neutral' basis, is a radical departure from previously existing Establishment Clause doctrine. Although there were previous cases in which the neutrality of state aid programmes had been cited as an important factor in the Court's decisions to sustain those programmes [32], Mitchell was the first case in which a plurality of the Court indicated that this factor might supplant all of the requirements for state-aid programmes that the Court had previously established. Although the plurality distinguished cash grants, citing the 'special Establishment Clause dangers' that they present [33], the plurality's view that 'neutrality' in operation has a potentially powerful role in Establishment Clause cases is a clear departure from existing Supreme Court doctrine. Whether a majority of the Court will ultimately adopt this approach remains to be seen.

The final form of establishment - that of the assumption by religious institutions of essentially public functions - occurs when civic authority and religious authority are united, in form, or otherwise jointly exercised. The Court has held that the mere appearance of a joint exercise of ... authority by Church and State' violates the principle of equality by providing 'a significant symbolic benefit to religion in the minds of some by reason of the power conferred.' [34] The fusion of government and religious institutional authority inevitably results in 'official support of ... the tenets of one or all orthodoxies' [35], with the violations of conscience and political and social divisiveness which such favouritism creates.

As these doctrinal summaries suggest, the principle of equality-itself a bedrock principle of First Amendment interpretation-has long been in tension with other First Amendment guarantees. To date, the Court's majorities have endorsed the idea that equality requires the equal treatment of individuals, regardless of religious identity or belief, and that it prohibits the alliance of government with any religious sect. Beyond this point the Court has refused to go. It has refused, in particular, to hold that religion must be treated on an equal basis with non-religion in all contexts; instead, it has maintained the view that religion, as a constitutional matter, enjoys special privileges (religious conscience is protected in ways that other kinds of conscience are not) and is subject to special disabilities (although secular ideologies can be explicitly and intentionally adopted by government, religious ideologies cannot). The theoretical 
underpinning of these holdings is the belief that religion is 'different' from other (secular) beliefs. Very recently, advocates of state funding for religious schools have challenged this premise. It is to that challenge that we now turn.

\section{THE NEW 'EQUALITY’ CHALLENGE}

Emboldened by the plurality opinion in the Mitchell case, and polls that indicate at least some degree of public support for state funding of religious education, advocates of state aid for religious elementary and secondary schools have launched a recent and vigorous offensive along the following lines. They argue that we must reconceive our understanding of Establishment Clause jurisprudence, and the factual premises upon which it stands. Traditional concerns about the effects of state funding of religious institutions do not, they argue, reflect the political and social conditions that now exist in the United States. Although there may have been periods in American history when public funding of religious institutions posed particular dangers, requiring-as a result-extreme prophylactic measures, those conditions do not characterise American society today. Today, they argue, religion is seen as no different from other deep personal commitments that individuals hold, and religious tolerance is an accepted part of political and social life. For instance, there is, under current conditions, nothing more inherently coercive or offensive to taxpayers about the funding of the religions of others, than there is about the funding of any other activities or programmes with which taxpayers disagree. Concern about the corruption of religious or government institutions from state-aid programmes is also argued to be an antiquated idea, which ignores the sophistication of these institutions. In the view of these advocates, the most important and enduring First Amendment value is freedom of individual choice in religious matters, and the equal treatment of religious and secular educational institutions by government. When government simply supports-in a neutral and evenhanded manner - those religious and secular educational institutions that parents and students independently choose, the opportunity for free religious exercise is maximised, and discrimination against religious persons - for their choice of religious schools-is eliminated.

These challenges are powerful, at face value. The ideas that 18 th-century concerns do not necessarily describe 21 st-century conditions, and that free religious exercise and the avoidance of discrimination are the most important principles in our understandings of First Amendment guarantees, have great intuitive appeal. Should our ideas about the funding of religious educational institutions be reconceived along these lines? Let us examine these ideas more closely.

The idea that the coerced funding of religion is no different from the coerced funding of other institutions or activities strikes at the heart of the idea that religion is 'different' - that it has particular value and particular power in human lives. Previously, political and judicial decisionmakers have assumed that the special character of religion requires both its special protection (in the form of protected 'free exercise') and its special disabilities (in the form of its institutional exclusion from government).

Is this assumption no longer true? In particular, should the idea that compelled taxpayer funding of the religions of others inflames no particularly dangerous or divisive passions now be the assumption that undergirds our understanding of church-state issues? Is - for instance - the prospect of government funding of religious schools no more divisive, or disturbing, than a decision to fund the National Gallery of Art or the Boy Scouts [36]? 
A test of this hypothesis of religious benignancy and religious tolerance as the dominant view in the United States today was recently posed by a proposal by President George W. Bush to channel government money to religious charities. As proposed by his newly opened Office of Faith-Based and Community Initiatives, the Bush plan would greatly expand government funding of sectarian social services, including those whose programmes include overtly evangelical or 'conversion-centered' objectives. The plan is an outgrowth of research which establishes the effectiveness of religious charities, and the belief that greater government involvement with religious organisations is something of which the vast majority of Americans now approve.

Expecting enthusiastic support from religious organisations, particularly those associated with the 'religious right', the Bush administration was taken aback when conservative evangelical Christians - who have argued for years that current funding restrictions discriminate against religious groups - reacted with alarm to the Bush plan. Pat Robertson, for instance-a leading evangelical Christian figure and co-author of the book 'Compassionate Conservatism', a phrase which President Bush repeatedly invoked on the presidential campaign trail-has called the plan 'appalling,' because it could result in government contracts for programmes run by 'non-Western religions' and newer religious movements like the Church of Scientology, the Hare Krishna movement, or the Unification Church [37].

The problem, as commentator Steven Waldman has pointed out, is that many Americans embrace 'a limited form of pluralism,' one that tends to be tolerant of mainstream forms of Christianity, Judaism, and Islam (religions in the 'Abrahamic tradition'), but is decidedly intolerant of others [38]. Indeed, when asked in a recent New York Times/CBS News Poll whether it would be 'a good idea for the federal government to give money to religious organisations to provide social services like job training and drug treatment counseling', 66\% of the respondents answered affirmatively. However, when asked whether this would be true 'if ... the government would be giving money to religious organisations like the Nation of Islam, the Church of Scientology, and the Hare Krishnas', only 29\% agreed [39]. One can safely speculate that even fewer would have approved, had radical groups such as the Children of God, the Branch Davidians, or Wiccans been included in the inquiry. Concerns about the violation of personal conscience, political divisiveness, and the general power of religion in human lives might seem like historical artifacts when the government funding plan is envisioned to fund only 'acceptable' or 'mainstream' faiths; the situation is quite different when non-mainstream, non-traditional, even 'dangerous' religions are included.

If the problems are serious when the funding of social service organisations is at issue, they are compounded when one considers the funding of religious elementary and secondary schools. Most citizens in the United States would probably not feel a tremendous violation of conscience or other anxiety if they were compelled, through taxation, to fund mainstream Christian, Jewish, or Islamic schools, as long as those institutions adhere to the mainstream values which the majority of citizens believe are critical to the formation of future citizens and with which they feel culturally comfortable. Indeed, when pressed (for instance) about the operation of current religious school funding proposals, it is these institutions that advocates envision as the recipients of state funds. What if - instead-recipient institutions adhere to the tenets of radical sects, or reject the idea of civil authority, or teach ideas of religious hatred or racial bigotry? Would the funding of such schools be viewed so benignly?

Admitting - perhaps - that the potential for impassioned reactions and divisiveness 
exists, advocates of state funding for religious schools suggest several ways to minimise these conflicts. First, they argue that the practices or teachings of participating schools could be monitored and controlled, either by denying participation by particularly offensive groups outright, or by enumerating particular practices and teachings that are unacceptable in participating schools. For instance, schools run by religious 'cults' that lack particular institutional credentials could be excluded, or schools that engage in discriminatory practices or that otherwise violate the public policy of the state could be disqualified [40].

Such solutions, however, immediately encounter insuperable problems. Any attempt to distinguish 'acceptable' from 'unacceptable' religious groups will contravene the fundamental Establishment Clause principle that the religious beliefs of all persons must enjoy equal standing before the law. The government could no more exclude Scientologists, the Unification Church, the Branch Davidians, or the Nation of Islam from a 'neutral' school funding scheme than it could exclude them from any other government benefit or programme ostensibly open and available to all. Once the general Establishment Clause barrier to the funding of religious groups is breached, there is no constitutionally acceptable ground for government's picking and choosing among religious groups for receipt of government funding. As the Supreme Court has stated, '[i]f there is any fixed star in our constitutional constellation, it is that no official, high or petty, can prescribe what shall be orthodox in politics, nationalism, religion, or other matters of opinion ...' [41]. Government choice of particular religious groups would 'resurrect the very discriminatory treatment of religion which the Constitution sought forever to forbid' [42]. From any point of view, discrimination on the basis of the identity of the sponsoring religious organisation would clearly be beyond the constitutional pale.

The idea that government might prescribe or control certain practices, policies, or teachings of participating religious schools holds superficial promise, but also quickly breaks down. It might be fairly easy, for instance, for government to prohibit race discrimination in admissions, on the theory that this is a practice which is easily monitored, and general constitutional prohibitions on race discrimination outweigh any competing arguments that religious schools might conceivably make. When other practices or activities of religious schools are considered, however, the ease of prohibition quickly evaporates. Let us consider, for instance, common practices such as preferential admissions for co-religionists, or religious or gender discrimination (on religious grounds) in the hiring of faculty and staff. Where religiously based (but discriminatory) practices in admissions and hiring are concerned, the conclusion that state civil rights guarantees would necessarily trump the free exercise rights of those who run such schools is very far from certain. Indeed, it is precisely because of the power of free exercise claims that religious institutions enjoy broad institutional exemptions from religious discrimination claims under existing civil rights laws [43].

When one moves beyond specifically identified policies and practices to restrictions on the content of teaching in religious schools, constitutional problems become even more severe. Even if religious schools were to accept such government intrusion as the price for government money - a very unlikely event [44] — such restrictions might well be held by the courts to be 'unconstitutional conditions' [45], or unlawful attempts by government to condition the receipt of public money on the relinquishment of constitutional rights. Moreover, how such restrictions-even if constitutional-could be enforced, without continuing and intrusive surveillance of religious classrooms, is difficult to imagine. Although religiously based teachings-such as ideas that the 
sponsoring religion is 'true' and other religions are 'false', that women are by nature inferior to men, that AIDS is a curse against homosexual sinners, or that racial hierarchies are ordained by God-might be highly offensive and condemned by many, their eradication from publicly funded religious classrooms would be very difficult (if not practically impossible) to implement.

In view of the extraordinarily difficult problems involved in controlling the activities of religious schools, some state-aid advocates have abandoned this approach and advanced another. Under this new approach, advocates argue that a funding programme can eliminate - through its structure - any legal or publicly perceived connection between the state funding action and the recipient religious schools. Under these 'voucher' plans, state grants are given to students and their parents, who independently choose religious or nonreligious schools. It is argued that since- - under this scheme-it is private choice which acts as the operative or 'causative' agent, there is no legal or practical connection between the state funding action and the ultimate religious use. Giving vouchers of this sort to students and their parents is no different, it is argued, from giving welfare cheques to individuals, who can use that money for religious purposes. Just as the use of welfare money for religious purposes creates no particular public discomfort, neither will the use of voucher money for religious schools. This plan will, in addition, minimise the danger of corruption of government and religious institutions which is usually involved in government funding plans. Because government has no role in choosing religious recipients, there will be no unseemly, and dangerous, scramble for government largesse.

Let us consider, first, the issue of divisiveness. Will the divisiveness that comes from public funding of religious schools be eliminated through the simple use of 'private choice'? Will state payments, under voucher programmes, be seen-legally and practically - in the way that welfare cheques, or state employment cheques, now are?

To answer this question, we must analyse the nature of the underlying transactions. If the state programme simply involves the payment of state funds to recipient individuals, without more-if the state has no interest or concern beyond the simple act of distribution - then the connection between the state act and the ultimate recipient might be said, quite accurately, to be absent. This is true, for instance, when welfare money is given to recipients, who may use that money as they like. Although the state is aware that welfare funds could conceivably be used for religious purposes, it is neither an anticipated nor an important part of the state's funding programme that this use will, in fact, occur. The purposes and functions of the programme-to provide individual recipients with the means to buy food, housing, and other necessities - are completely unrelated to this possible, ultimate use. Indeed - far from fulfilling the purposes of the state programme - this use might more readily be seen as in derogation of them.

If, on the other hand, the state programme has - as its purpose and effect-the funding of particular institutions, the fact that an individual conducts that transfer has little legal or practical significance. Under school voucher plans, for instance, individuals who receive voucher funds are authorised to transfer that money to religious schools; indeed, it is the purpose of such plans that students who attend such schools will, in fact, do so. The plan exists because of the interest that the state retains-not in the act of distribution to the individual-but in the education that religious schools provide. Private schools are permitted, under state law, to undertake the public educational task which the state is otherwise obligated to perform. The state remains, as a result, vitally interested in the adequate funding of those private schools. Under an educational voucher plan, the choices that are made by individuals in distributing state funds are 
not made for purposes or ends in which the state has no interest; they are made in the execution of a programme that is infused-both before and after the individual distributive decision-with vital state concerns.

The idea that the channeling of public money to religious educational institutions through voucher plans will eliminate the divisiveness which is otherwise involved in public funding of religious schools ignores the operational realities of such programmes, and the public's knowledge of those realities. When it was argued two decades ago that a state could (through a 'neutral' programme) provide textbooks to students who attended private, all-white academies, because those academies received this aid through the mechanism of 'private choice', neither the public nor the courts were under any illusion as to what this programme, in fact, was [46]. If state money is given to students and their parents, who are authorised to transfer this money to religious-including extremely divisive-religious schools, the laundering of this money through 'private choice' will not eliminate the problems of divisiveness and coercion which state funding of these schools involves.

The other reasons for restraint of state-aid programmes - that financial enmeshment of church and state is damaging to both religious and government institutions - is likewise not eliminated by the simple expedient of private choice in proposed voucher plans. The true source of the funding involved will be obvious to religious institutions and government alike. With large amounts of funding - indeed, complete funding - potentially at stake, it is difficult to see how the scramble of religious institutions for government largesse, and the merger of political and religious issues, will be eliminated under such programmes.

A determination that voucher plans do not eliminate traditional Establishment Clause dangers does not, of course, address the final argument of state-aid advocates: that only the equal funding of religious schools will end the discrimination against religious persons-for their choice of religious schools-that current law assumes. Equality and religion must, however, be understood in a context of all fundamental rights and all constitutional guarantees. As long as 'religion' remains something that is particularly valuable, particularly powerful, and particularly feared, its equal treatment - for both protective and prohibitive purposes - will be impossible. Equality, in this context, is a false premise. It denies the special character of religion, as a constitutional category and as a force in individual and collective life.

\section{CONCLUSION}

In any society in which religious diversity and consequent hostilities exist, the balance that is struck among religious freedom, parental rights, and state educational objectives will necessarily be an uneasy one. The elevation of any one of these to absolutely protected status will threaten the others, and will jeopardise the complex and delicate social fabric of which all are a part.

The right of parents to educate their children in religious schools of their choice is a precious right, and one which is-at this point in American history-beyond legal challenge. The rights of parents to choose such schools does not, however, mean that others in society must be compelled to fund that choice. The demand of religiousschool advocates that the public fund religious schools on a par with secular ones ignores the fact that religion and politics constitute a volatile mixture, which tends to undermine the atmosphere of tolerance upon which all religiously diverse societies depend. To believe that the United States is exempt from this truth is to believe that 
we (as individuals) are exempt, somehow, from one of the most consistent lessons of human history.

\section{NOTES}

[1] Everson v. Board of Education, 330 U.S. 1 (1947).

[2] For discussion of religious practices and persecution in the American colonies, and the struggles of reformers, see Laura Underkuffler-Freund, 'The Separation of the Religious and the Secular: A Foundational Challenge to First Amendment Theory', 36 William \& Mary Law Review 837 (1995).

[3] See United States Constitution Article VI (' $[\mathrm{N}]$ o religious Test shall ever be required as a Qualification to any Office or public Trust under the United States').

[4] Id. Amendment I.

[5] See, e.g., Cantwell v. Connecticut, 310 U.S. 296 (1940) (Free Exercise Clause); Everson v. Board of Education, 330 U.S. 1 (1947) (Establishment Clause).

[6] United States v. Ballard, 332 U.S. 78, 86 (1944).

[7] See, e.g., Braunfeld v. Brown, 366 U.S. 599, 603-05 (1961).

[8] See, e.g., Hernandez v. Commissioner, 490 U.S. 680, 699 (1989); Thomas v. Review Board, 450 U.S. 707, 717-19 (1981).

[9] See Wisconsin v. Yoder, 406 U.S. 205 (1972).

[10] See Employment Division v. Smith, 494 U.S. 872, 878-90 (1990); Lyng v. Northwest Indian Cemetery Protective Association, 485 U.S. 439, 449-52 (1988).

[11] Employment Division v. Smith, 494 U.S. 872, 888 (1990).

[12] See McDaniel v. Paty, 435 U.S. 618 (1978) (plurality opinion).

[13] Board of Education of Kiryas Joel Village School District v. Grumet, 512 U.S. 687, 696 (1994) (plurality opinion). See also Rosenberger v. Rector and Visitors of the University of Virginia, 515 U.S. 819, 839 (1995); Lamb's Chapel v. Center Moriches Union Free School District, 508 U.S. 384 (1993).

[14] Engel v. Vitale, 370 U.S. 421, 431 (1962).

[15] Lemon v. Kurtzman, 403 U.S. 602, 622 (1971).

[16] Objections on the latter ground have been vigorously pressed by fundamentalist Christian groups in recent years. See, e.g., Smith v. Board of School Commissioners, 655 F. Supp. 939 (S.D.Ala.) (claim that 'a man-centered belief-system, ... [known] by the appellation 'secular humanism', [was] promoted in the public schools' in violation of the Establishment Clause) reversed, 827 F.2d 684 (11th Cir. 1987).

[17] See, e.g., School District v. Schempp, 374 U.S. 203, 223-25 (1963) (Bible reading); Engel v. Vitale, 370 U.S. 421, 424-36 (1962) (prayer). In a recent case, challenge was made to a state law which required a time of 'meditation or voluntary prayer' in public schools, on the ground that this was a religious exercise. The Supreme Court held that this law was unconstitutional, based on evidence that state legislators were motivated by a desire to circumvent the Court's prior rulings on school prayer, and intended to advance religion in the public schools, when the law was passed. Wallace v. Jaffree, 372 U.S. 38, 56-60 (1985).

[18] See Edwards v. Aguillard, 482 U.S. 578, 591 (1987) (state law which prohibited the teaching of the theory of evolution in public schools unless accompanied by 
instruction in 'creation science'-the Biblical story of creation-violated the Establishment Clause, because ' $[\mathrm{t}$ ] he preeminent purpose of the [state legislature] ... was clearly to advance the religious viewpoint'); Epperson v. Arkansas, 393 U.S. 97, 107-109 (1968) (state law prohibiting the teaching of evolution in public schools violated the Establishment Clause, where religious advertisements and 'campaign' for passage of the law established legislators' religious motivations). Compare, however, Board of Education v. Mergens, 496 U.S. 226, 249 (1990) (plurality opinion) (even if some legislators were motivated by a desire to protect religious speech, that alone would not invalidate the Act; 'what is relevant is the legislative purpose of the statute, not the possibly religious motives of the legislators ... Because the Act on its face grants equal access to both secular and religious speech, ... the Act's purpose was not 'to endorse or disapprove of religion', (quoting Wallace v. Jaffree, 472 U.S. 38, 56 (1985) (emphasis in original).

[19] Everson v. Board of Education, 330 U.S. 1, 16 (1947).

[20] See, e.g., Bowen v. Kendrick, 487 U.S. 589, 608-13 (1988) (teenage counselling services); Tilton v. Richardson, 403 U.S. 672, 679-82 (1971) (plurality opinion) (higher education in secular subjects).

[21] Hunt v. McNair, 413 U.S. 734, 743 (1973).

[22] Walz v. Tax Commission of New York, 397 U.S. 664, 671 (1970).

[23] See, e.g., School District v. Ball, 473 U.S. 373, 395 (1985), overruled on other grounds, by Agostini v. Felton, 521 U.S. 203 (1997); Lemon v. Kurtzman, 403 U.S. 602, 621 (1971); Everson v. Board of Education, 330 U.S. 1, 15-16 (1947).

[24] Engel v. Vitale, 370 U.S. 421, 431 (1962).

[25] See Lemon v. Kurtzman, 403 U.S. 602, 622 (1971) (political division along religious lines-a consequence of financial enmeshment of religion with government-'was one of the principal evils against which the First Amendment was intended to protect').

[26] See, e.g., Board of Education v. Allen, 392 U.S. 236 (1968).

[27] See, e.g., Wolman v. Walter, 433 U.S. 229, 244 (1977); Board of Education v. Allen, 392 U.S. 236, 248 (1968). Some cases have pushed the boundaries of 'incidental' financial aid to questionable lengths. See, e.g., Tilton v. Richardson, 403 U.S. 672 (1971) (plurality opinion) and Roemer v. Board of Public Works, 426 U.S. 736 (1976) (upholding, under traditional tests, state subsidies and federal construction grants for buildings devoted to the teaching of secular subjects in religiously affiliated colleges and universities).

[28] See Agostini v. Felton, 521 U.S. 203, 229 (1997).

[29] Id. at 231.

[30] 530 U.S. 793 (2000).

[31] Id. at 809-14.

[32] See, e.g., Mueller v. Allen, 463 U.S. 388, 399 (1983) (involving tax deductions for religious elementary and secondary school expenses); Zobrest v. Catalina Foothills School District, 509 U.S. 1, 9-14 (1993) (involving federal funds to provide an interpreter for a deaf student enrolled in a religious high school); Witters v. Washington Department of Services for the Blind, 474 U.S. 481, 486-89 (1986) (involving state vocational assistance grants to pay for the partial costs of a college student's concededly religious vocational training).

[33] Mitchell v. Helms, 530 U.S. 793, 818-19 (2000) (quoting Rosenberger v. Rector \& Visitors of the University of Virginia, 515 U.S. 819, 842 (1995)). 
[34] Larkin v. Grendel's Den, 459 U.S. 116, 125-26 (1982).

[35] School District v. Schempp, 374 U.S. 203, 222 (1963).

[36] Religious individuals and institutions must also be aware that this 'no difference' paradigm is a two-edged sword: for what it gives to freedom of conscience and individual choice through eligibility of religious institutions for government largesse, it takes from these very same values by depriving religious belief and exercise of the reasons for their special standing and special protection in law. See Laura S. Underkuffler, The Price of Vouchers for Religious Freedom, $78 \mathrm{U}$. Detroit Mercy L. Rev. 101 (2000).

[37] See Laurie Goodstein, 'Bush's Charity Plan Is Raising Concerns for Religious Right', The New York Times, March 3, 2001, at A1.

[38] See Steven Waldman, 'Doubts Among the Faithful', The New York Times, March 7, 2001, at A19.

[39] Richard L. Berke and Janet Elder, ' 60 Percent Favor Bush, But Economy is Major Concern', The New York Times, March 14, 2001, at A1. Indeed, much of the early enthusiasm for the Bush idea of increased partnerships between religion and government was based upon similar misconceptions. As one commentator has observed, 'Many of the most conservative Christians cottoned to George W. Bush's campaign rap about the importance of religion. Since he kept talking about Jesus, it was easy for them to assume that prayer in school meant Christian prayer in school; private school vouchers meant Christian school vouchers.' The problem, however, 'is that it's tough to be president of the United States and say that certain religions are all right and others aren't. It's even harder to tell what is a religion and what isn't: Hare Krishnas, viewed here as cult-like, are far more accepted in India.' Waldman, note 38 supra.

[40] For instance, a voucher plan adopted by the state of Ohio excludes schools that 'discriminate on the basis of race, religion, or ethnic background; advocate or foster unlawful behavior; or teach hatred of any person or group on account of race, ethnicity, national origin, or religion.' Simmons-Harris v. Zelman, 234 F.3d 945, 948-49 (6th Cir. 2000). In a lengthy opinion, the federal appellate court, using traditional principles, held that this programme violates the Establishment Clause. Perhaps reflecting the passions and divisiveness that issues create, both majority and dissenting opinions are written in particularly bitter terms. For instance, the majority states that it would 'pause to briefly address the dissent, not for the purpose of dignifying its hyperbole, but to quash any putatively substantive argument which may have found its way through the gratuitous insults.' Id. at 962. The dissent, in its turn, accuses the majority of failing to engage in 'any independent constitutional analysis', of holding 'nativist hostility toward religious schools', of advancing 'utterly meritless arguments', and in engaging in an 'exercise in raw judicial power ... [that has] no basis in the First Amendment or in the Supreme Court's Establishment Clause jurisprudence.' Id. at 963, 973, 971, 974.

[41] West Virginia State Board of Education v. Barnette, 319 U.S. 624 (1943).

[42] Id. at 658 (Frankfurter, J., dissenting).

[43] For instance, under section 703(e)(2) of Title VII of the Civil Rights Act of 1964, the primary federal statute dealing with discrimination in employment, an employer may employ persons of a particular religion (to the exclusion of others) if the employer is an educational institution that is, in whole or in substantial part, owned, supported, controlled, or managed by a particular religion or a particular 
religious organisation, or if the curriculum of the institution is directed toward the propagation of a particular religion. 42 U.S.C. Sec. 2000e-2(e)(2). For a general discussion of the meshing of civil rights laws and religious guarantees, see Laura S. Underkuffler, ' 'Discrimination' on the Basis of Religion: An Examination of Attempted Value Neutrality in Employment', 36 William \& Mary Law Review 581 (1989).

[44] Indeed, the mere possibility of government funding of religious social service programmes has raised alarms by religious groups that government will attempt to meddle in their missions and messages. See Goodstein, note 37 supra.

[45] The Supreme Court has held in several cases that government could not condition a government privilege on relinquishment of a constitutional right. See, e.g., Speiser v. Randall, 357 U.S. 513 (1958) (statute that conditioned the availability of a tax exemption on the relinquishment of First Amendment rights held unconstitutional).

[46] See, e.g., Norwood v. Harrison, 413 U.S. 455 (1973).

Correspondence: Professor Laura S. Underkuffler, Duke University School of Law, Box 90360, Durham, NC 27708-0360, USA. 
Copyright of Oxford Review of Education is the property of Carfax Publishing Company and its content may not be copied or emailed to multiple sites or posted to a listserv without the copyright holder's express written permission. However, users may print, download, or email articles for individual use. 